\title{
THE IMPLICATIONS OF L-CARNITINE AND SILYMARIN SUPPLEMENTATION ON GROWTH PERFORMANCE AND SOME BLOOD PARAMETERS OF BROILERS
}

\author{
M.A. MOUSA ${ }^{1}$ and A.S. OSMAN ${ }^{2}$ \\ ${ }^{1}$ Sohag University, Faculty of Vet. Med., Department of Nutrition and Clinical Nutrition \\ ${ }^{2}$ Sohag University, Faculty of Vet. Med., Department of Biochemistry
}

Received: 31 December 2015; Accepted: 31 January 2016

\begin{abstract}
Chick performance, carcass traits and some blood biochemical parameters of broilers fed basal diet supplemented with L-carnitine or silymarin were studied for 42 days in the experiment. This study was conducted on 300 chicks (Ross 308 hybrid) divided randomly into three groups, (100 chicks per each) and each group was subdivided into four replicates (25 chicks for each). Chicks in the first group (C) were fed ad-libitum on the basal control diets (starter from 1 to 21 days of age, and grower- finisher from 22 to 42 days of age) without addition of L-carnitine and silymarin. Birds in the second group (L) received the same basal diet supplemented with L-carnitine $(300 \mathrm{mg} / \mathrm{kg}$ diet) while, chicks in the third group (S) fed on basal diet supplemented with silymarin $(160 \mathrm{mg} / \mathrm{kg}$ diet $)$ during two experimental periods. The results showed that, supplementation of silymarin and L-carnitine improved significantly body weight gain at starting period. The highest body weight gain was recorded with silymarin supplemented group $(662 \pm 20 \mathrm{~g})$ in comparison with control (593.5 $\pm 20 \mathrm{~g})$. At the end of the experiment (42 days), the best cumulative weight gain and feed conversion recorded in silymarin supplemented group $(2163 \pm 23 \mathrm{~g} \& 1.9)$ followed by L-carnitine supplemented group (2103.5 $\pm 16 \mathrm{~g} \& 1.94)$ while the birds fed on control diet had the worst values $(1893.8 \pm 65 \mathrm{~g} \& 1.96)$. Abdominal fat deposition of L and S groups were significantly lower than control group, while no significant differences were observed in dressed carcass and breast muscle weights. From the results of this study, it can be concluded that, the addition of silymarin to broiler diets significantly improved the body weight gain and feed conversion indices all over the period of raising, while L-carnitine improved growth performance of broilers at growing-finishing period (high energy diet). Finally, it is recommended that we can use both silymarin and Lcarnitine as feed additives at growing-finishing period.
\end{abstract}

Key words: Broilers, silymarin, L-carnitine, growth performance, carcass traits.

\section{INTRODUCTION}

Poultry market is one of the fastest-growing businesses in Egypt. Latterly, meat-type chicks have been intensively selected for body weight gain. This selection strategy has resulted in a greater growth rate with improved feed conversion efficiency. However, excessive fat deposition is one of the undesirable consequences of selection for increased growth of modern broiler chicks. Accumulation of fat in broiler carcasses considers a waste product to consumers, nutritional and health aspects of their food so; nutritionists continuously try to mediate this problem by means of dietary manipulations, in order to achieve the desired characteristics of growth and carcass composition (Tabeidian et al., 2010).

Corresponding author: Dr. M.A. MOUSA

E-mail address: dr_m_mousa@yahoo.com

Present address: Sohag University, Faculty of Vet. Med.,

Department of Nutrition and Clinical Nutrition
Carnitine has gained interest in the recent years as a potential feed additive for improving chicken meat production. Carnitine is synthesized from methionine and lysine with magnesium-ATP, vitamins C, B6, niacin and iron, which are all necessary as catalysts (Bremer, 1983). L-carnitine requirement was not considered due to endogenous biosynthesis. However, Parsaeimehr et al. (2012) reported that L-carnitine becomes an essential nutrient under certain circumstances, such as limited carnitine biosynthesis in young animals, diets low in carnitine content, conditions of stress, higher performance, and diets rich in fat. Murali et al. (2015) stated that L-carnitine plays a key role in energy metabolism of cells, mainly by transferring long-chain acyl groups from cytoplasm to mitochondrial matrix for oxidation by the fatty acid oxidation complex. L-carnitine supplementation may have a beneficial effect on broiler nutrition status, mainly due to its sparing effect on its precursor's 
lysine and methionine (Hossininezhad et al., 2011). In addition, Murali et al. (2015) investigated the antioxidant properties of L-carnitine which increases the levels and activity of antioxidant enzymes such as glutathione peroxidase and superoxide dismutase. Lcarnitine has a role in stabilizing cell membranes and in regulating the function of ion channels because of reducing the amount of oxidative damage that happened in membrane phospholipids (Kalaiselvi and Panneerselvam, 1998). Rabie et al. (1997) and Parsaeimehr et al. (2012) found that adding Lcarnitine improved the growth performance of broilers. Some authors provided conclusive evidence that L-carnitine has a beneficial effect on broilers performance, while others held that it has not or even adversely affects production results and mortality (Golzar Adabi et al., 2011). Harpaz et al. (1999) demonstrated that adding L-carnitine resulted in protection against cold stress, while it had a significant response to the acute heat stress (Whitehead et al., 1997). In addition, it strengthened chick's immune function by enhancing antibody responses (Deng et al., 2006).

Silymarin exhibits chemopreventive activity against chemical, viral, bacterial and fungal toxins, inhibits lipid peroxidation, and stabilizes the cell membranes of the liver parenchyma (Opletal and Skrivanova, 2010). Silymarin presents a pharmacologically effective substance containing four main constituents: silybin, isosilybin, silychristin and silydianin (Ding et al., 2001). Fraschini et al. (2002) and Suchy et al. (2008) literatures stated that silymarin acts in four different ways: as an antioxidant, absorber and regulator of the intracellular glutathione; as a stabiliser and regulator of cell membrane permeability that prevents the entering of hepatotoxic substances into hepatocytes; as the ribosomal RNA synthesis promoter simulating regeneration of the liver; and as an inhibitor of the transformation of liver stellate cells into myofibroblasts - the process responsible for deposition of collagen fibres in liver. Furthermore, absorption of free radicals is considered as a key mechanism securing liver protection (Fraschini et al., 2002). Silymarin supplementation increased productive and reproductive performances and improved livestock health status of animals (Tedesco, 2001). Skottova and Krecman (1998); Crocenzi and Roma (2006) pointed out its potent anticholestatic activity and the possibility of a direct impact of silymarin on the cholesterol metabolism by means of its biosynthesis inhibition. L-carnitine and silymarin are known to increase antioxidant status during aging (Arenas et al., 1998 and Fraschini et al., 2002). The present study was conducted to evaluate the effects of supplementation silymarin or Lcarnitine to broiler diets on the performance, carcass traits and some blood parameters.

\section{MATERIALS AND METHODS}

Experimental chicks, housing, and management: This experiment was performed on Ross 308 hybrid $(\mathrm{n}=300)$ chicks which fattened on conventional deep litter system. Wood shavings were used as bedding material. The trial was conducted from day 1 to day 42 of chick's age. Room temperature and humidity were controlled and lighting system was 24 hours light. Table 1 shows chemical composition of control; and experimental rations. The rations were calculated according to the recommended nutrient requirements (NRC, 1994). Chicks were fed ad-libitum, and health status was evaluated daily. All broilers were vaccinated against Newcastle and infectious bronchitis at hatch and IBD at 15 days old.

\section{Experimental design and feeding:}

Three hundred one -day old chicks were divided randomly into three groups, (100 chicks per each) and each group was subdivided into four replicates (25 chicks for each). Chicks in the first group (C) were fed ad-libitum on the basal control diets (starter from 1 to 21 days of age, and grower- finisher from 22 to 42 days of age) without addition of L-carnitine or silymarin. Birds in the second group (L) received the same basal diet supplemented with L- carnitine (300mg/kg diet) while, chicks in the third group (S) fed on basal diet supplemented with silymarin $(160 \mathrm{mg} / \mathrm{kg}$ diet) during two experimental periods. A $3 \times 4$ replicates arrangement of treatments was used in Exp. A standard basal diet was formulated from maize, soybean meal, concentrate mixture and sunflower oil along with other ingredients to meet minimum nutrient requirements of broiler, as established by National Research Council (NRC, 1994) as shown in Table 1. 
Table 1: Ingredients and chemical composition of basal control diets

\begin{tabular}{l|c|c}
\hline \multicolumn{1}{c}{ Ingredients } & $\begin{array}{c}\text { Starter diet } \\
0-21 \text { days of age }\end{array}$ & $\begin{array}{c}\text { Grower-finisher diet } \\
\text { 22-42 days of age }\end{array}$ \\
\hline Corn grain & 56 & 63.95 \\
\hline Soy bean meal & 28 & 21 \\
\hline Conc. mixture & 10 & 10 \\
\hline Sunflower oil & 2.2 & 1.6 \\
\hline Di-calcium phosphate & 2 & 0.8 \\
\hline Ca-carbonate & 0.8 & 0.3 \\
\hline Salt & 0.3 & 0.1 \\
\hline Na bicarbonate & 0.25 & 0.3 \\
\hline Mineral and Vitamins premix $*$ & 0.3 & 0.1 \\
\hline Methionine & 0.1 & 0.05 \\
\hline Lysine & 0.05 & 100 \\
\hline Total & 100 & 3176 \\
\hline Calculated analysis & & 18 \\
\hline Metabolizable energy $(\mathrm{kcal} / \mathrm{kg})$ & 2988 & 0.90 \\
\hline Protein $(\%)$ & 21 & 0.8 \\
\hline Calcium $(\%)$ & 1.0 & 1.2 \\
\hline phosphorus & 0.9 & 0.57 \\
\hline Lysine $(\%)$ & 1.4 & \\
\hline Methionine $(\%)$ & 0.58 & \\
\hline
\end{tabular}

* Premix provided the following per kg of diet: vitamin A (vitamin A acetate) 7,718 IU; cholecalciferol 2,200 IU; vitamin E (source unspecified) $10 \mathrm{IU}$; menadione, $0.9 \mathrm{mg}$; B12, $11 \mu \mathrm{g}$; choline, $379 \mathrm{mg}$; riboflavin, $5.0 \mathrm{mg}$; niacin, 33 mg; D-biotin, $0.06 \mathrm{mg}$; pyridoxine, $0.9 \mathrm{mg}$; ethoxyquin, $28 \mathrm{mg}$; manganese, $55 \mathrm{mg}$; zinc, $50 \mathrm{mg}$; iron, $28 \mathrm{mg}$; copper,7 $\mathrm{mg}$; iodine, $1 \mathrm{mg}$; selenium, $0.2 \mathrm{mg}$.

\section{Tested parameters:}

Performance measurements:

Live body weight was measured to the nearest gram at the beginning of the experiment and at the end of the starter period (21 days old) and finisher period (42 days old). The amount of feed consumed was weekly recorded in each of the different experiment groups. The average amount of feed intake of each bird was calculated by dividing the weekly consumed food by its respective number of birds in each group at this week.

Body weight gain (BWG) was calculated by subtracti ng the average

initial LBW at a certain period from the average final LBW at the same period. Feed conversion was calculated by dividing feed consumption by total BW gain. Mortality was observed and recorded. Chicks Health status was evaluated daily.

\section{Carcass yields}

Prior to slaughter birds were given a feed withdrawal period of $12 \mathrm{~h}$. At the end of experiment, 12 birds were randomly selected from each group, weighed and slaughtered. Feathers were removed and chickens were eviscerated. Carcass yield was calculated.
Selected chickens were deboned and weighed breast muscle and abdominal fat. These values were calculated as a percentages of live weight.

\section{Blood biochemical Parameters}

Blood samples from three chicks of each group were collected by puncturing the wing vein. Blood samples were allowed to stand for one hour and centrifuged at a speed of $3.000 \mathrm{rpm}$ for 10 minutes. The clear serum was collected in sterilized disposable plastic tubes and stored at $-20{ }^{\circ} \mathrm{C}$ for further analysis. The individual serum sample was analyzed for total proteins, albumin, creatinine, triglyceride, cholesterol, and aspartate amino transferase (AST). Also, the methodology for each parameter was based on recommendations of the manufacturer of the analytical system.

\section{Statistical analysis:}

The data was statistically analyzed with the standard procedures of analysis of variance (ANOVA), using completely randomized block design as suggested by Steel and Torrie (1981). The statistical packages SAS (1998) were used to perform the above analysis on computer. 


\section{RESULTS}

The summary of the growth performance variables is listed in Table $2 \& 3$. Obtained data revealed that supplementation of silymarin and L-carnitine improved significantly $(\mathrm{p}<0.05)$ body weight gain at starting period (first three weeks of age) compared with control. The highest body weight gain was recorded by silymarin supplemented group $(662 \pm 20$ g) in comparison with control $(593.5 \pm 20 \mathrm{~g})$. At the end of the experiment ( 42 days), the best cumulative weight gain and feed conversion recorded in silymarin supplemented group $(2163 \pm 23 \mathrm{~g} \& 1.9)$ followed by broilers in L-carnitine supplemented group (2103.5 $\pm 16 \mathrm{~g} \& 1.94)$ while the birds fed on control diet had the worst values $(1893.8 \pm 65 \mathrm{~g} \&$ 1.96).

Table 2: Body weight gain (g/bird) of broilers during the experimental period

\begin{tabular}{l|c|c|c}
\hline Groups & $1-3$ weeks of age & $4-6$ weeks of age & $1-6$ weeks of age \\
\hline Control group (C) & $593.5 \pm 20^{\mathrm{b}}$ & $1300.3 \pm 58^{\mathrm{b}}$ & $1893.8 \pm 65^{\mathrm{b}}$ \\
\hline L-carnitine group (L) & $624.4 \pm 30^{\mathrm{b}}$ & $1479.1 \pm 39^{\mathrm{a}}$ & $2103.5 \pm 16^{\mathrm{b}}$ \\
\hline Silymarine group (S) & $662 \pm 20^{\mathrm{a}}$ & $1501 \pm 32^{\mathrm{a}}$ & $2163 \pm 23^{\mathrm{a}}$ \\
\hline
\end{tabular}

* Figures in the same column having the same superscripts are not significantly different $(\mathrm{P}<0.05)$

Concerning feed intake at starting period, L-carnitine supplemented group recorded lowest feed intake in comparison with control and silymarin supplemented groups (Table 3). Birds in the two experimental groups recorded numerical feed intake at growingfinishing period when compared with control, with the highest value scorded by silymarin supplemented group $(3260 \pm 22 \mathrm{~g})$. Regarding the cumulative feed consumption during the whole experimental period, silymarin supplemented group recorded numerically higher feed intake $(4120 \pm 80 \mathrm{~g})$ compared to Lcarnitine supplemented group $(4072 \pm 80 \mathrm{~g})$.

Table 3: Feed intake(g/bird) and final FCR of broilers during the experimental period

\begin{tabular}{l|c|c|c|c}
\hline Groups & $1-3$ weeks of age & $4-6$ weeks of age & $1-6$ weeks of age & FCR \\
\hline Control group (C) & $872 \pm 40$ & $3197 \pm 72$ & $4069 \pm 65$ & 2.15 \\
\hline L-carnitine group (L) & $829 \pm 35$ & $3243 \pm 61$ & $4072 \pm 80$ & 1.94 \\
\hline Silymarine group (S) & $860 \pm 20$ & $3260 \pm 22$ & $4120 \pm 74$ & 1.90 \\
\hline
\end{tabular}

* Figures in the same column having the same superscripts are not significantly different $(\mathrm{P}<0.05)$

Abdominal fat deposition of $\mathrm{L}$ and $\mathrm{S}$ groups were significantly lower than control group, while no significant differences were observed in dressed carcass and breast muscle weights (Table 4). Blood parameters appeared to be of particular interest mainly at the age of 42 days when $\mathrm{S}$ and $\mathrm{L}$ groups showed higher plasma protein levels (table 5).

Table 4: Carcass traits parameters of broiler at the end of the experiment

\begin{tabular}{c|c|c|c}
\hline Groups & $\begin{array}{c}\text { Dressed carcass } \\
\text { (\% of live body weight })\end{array}$ & $\begin{array}{c}\text { Breast } \\
\text { (\% of carcass weight })\end{array}$ & $\begin{array}{c}\text { Abdominal fat } \\
\text { (\% of live body weight })\end{array}$ \\
\hline$(\mathrm{C})$ & 65.17 & 37.53 & $1.96^{\mathrm{b}}$ \\
\hline$(\mathrm{L})$ & 653.6 & 36.3 & $1.6^{\mathrm{a}}$ \\
\hline$(\mathrm{S})$ & 65.49 & 37.44 & $1.88^{\mathrm{a}}$ \\
\hline
\end{tabular}

* Figures in the same column having the same superscripts are not significantly different $(\mathrm{P}<0.05)$

Table 5: Blood biochemical parameters of broiler at the end of the experiment

\begin{tabular}{l|c|c|c|c|c|c|c}
\hline Groups & $\begin{array}{c}\text { Protein } \\
(\mathrm{g} / 100 \mathrm{ml})\end{array}$ & $\begin{array}{c}\text { Albumin } \\
(\mathrm{g} / 100 \mathrm{ml})\end{array}$ & $\begin{array}{c}\text { Globulin } \\
(\mathrm{g} / 100 \mathrm{ml})\end{array}$ & $\begin{array}{c}\text { AST } \\
(\mathrm{U} / 1000 \mathrm{ml})\end{array}$ & $\begin{array}{c}\text { Cholesterol } \\
(\mathrm{mg} / 100 \mathrm{ml})\end{array}$ & $\begin{array}{c}\text { Triglycerides } \\
(\mathrm{mg} / 100 \mathrm{ml})\end{array}$ & $\begin{array}{c}\text { Creatinine } \\
(\mathrm{mg} / 100 \mathrm{ml})\end{array}$ \\
\hline$(\mathrm{C})$ & $3.94 \pm 0.26$ & $1.57 \pm 0.08$ & $2.37 \pm 0.1$ & $127.1 \pm 12$ & $111.49 \pm 11^{\mathrm{b}}$ & $64.28 \pm 28$ & 0.15 \\
\hline$(\mathrm{L})$ & $4.17 \pm 0.15$ & $1.63 \pm 0.09$ & $2.54 \pm 0.15$ & $139 \pm 23$ & $144 \pm 9^{\mathrm{a}}$ & $87 \pm 19$ & 0.15 \\
\hline$(\mathrm{S})$ & $4.3 \pm 0.34$ & $1.61 \pm 0.05$ & $2.69 \pm 0.11$ & $144.6 \pm 20$ & $108.9 \pm 17^{\mathrm{b}}$ & $83.48 \pm 24$ & 0.16 \\
\hline
\end{tabular}

\footnotetext{
* Figures in the same column having the same superscripts are not significantly different $(\mathrm{P}<0.05)$
} 


\section{DISCUSSION}

\section{Growth performance:}

The significant improvement of weight gain and higher feed intake of silymarin supplemented group may be attributed to its mechanisms of action that are antioxidant, cell membrane stabilizer and permeability regulator, as well as a promoter of DNA, RNA, and protein synthesis (Magliulo et al., 1973). Similarly, Gowda and Sastry (2000) confirmed a significant improvement of silymarin on body weight gain and attributed its effects to antioxidant activity in the protein synthesis stimulation by the bird's enzymatic system. The higher weight gain was reported by Chakarverty and Parsad (1991). In contrast to our results, Suchy et al. (2008) and Wojcik et al. (2002) observed that the addition silymarin as Silybum Marianum seed cakes caused a decrease in the weight gain and feed conversion ratio. This explained as the herbal seed be bitter in taste on have another anti-nutritional factor attributed to decrease growth and increase FCR.

Improvement of final body weight and decrease of FCR of L- carnitine supplemented group also attributed to L-carnitine plays an important role in energy metabolism of cells (Murali et al., 2015) and its sparing effect on its precursor's lysine and methionine (Hossininezhad et al., 2011). In addition, Murali et al. (2015) found that antioxidant activity of L-carnitine increases the activity of other antioxidant enzymes, L-carnitine has a role in stabilizing cell membranes and in regulating the function of ion channels (Kalaiselvi and Panneerselvam 1998).

The numerical increase of bodyweight gain and decrease feed intake of L group than control at starting period may be explained as 1-carnitine helps chicks for better assimilation of dietary protein and energy and has sparing effect of L-carnitine on essential amino acids (methionine and lysine). The significant increase of weight gain at finisher period could be attributed to the protective effects of kidney besides guarding the perfect metabolic pathway of fat and carbohydrate to growth and not for fat deposition. The significant increase of weight gain of $\mathrm{S}$ group in coordination with decrease feed intake than $\mathrm{C}$ control could be attributed to against toxins in feed and antioxidant, and simulating regeneration of the liver (Opletal and Skrivanova, 2010; Fraschini et al., 2002).

\section{Carcass Traits and blood parameters:}

Addition of L-carnitine to the diet did not affect carcass weight, carcass ratio and breast to the carcass weight (Table 5). Similar results obtained by Zhou et al. (2009) who found that L carnitine and silymarin supplementation to the diet did not change carcass trait, but decreased abdominal fat ratio. Interestingly, L-carnitine and silymarin addition to the diet induced higher leg ratio than the control group. This is a positive situation regarding the economic condition and this may be attributed to the effect of both L carnitine and silymarin in liver protection and improve of ribosomal enzymes and increase the activity and size of mitochondria in active muscle cells of thigh. Lien and Horng (2001) found negative effect of L-carnitine supplementation to the broiler chicken diet on carcass yield traits. Discrepancies between this study and other studies on carcass yield traits may be related to differences of silymarin source and L-carnitine and their doses.

In addition, a slight, but not significantly increase in triglyceride levels was observed in both treated groups, probably indicating an increase in metabolism, a reduction in hepatic storage of lipids or increase or increased lipid mobilization. Overall serum AST activity was higher for treated groups and a higher value $(\mathrm{p}<0.05)$ was recorded for $\mathrm{S}$ group. AST activity was found to be the most sensitive indicator of liver damage by Lumeij (1997) and was indicated as useful for diagnosis of fatty liver hemorrhagic syndrome by Yousefi et al. (2005). Birds normally have been reported to show serum AST activity up to $230 \mathrm{U} / \mathrm{L}$ (Coles, 1986). On this basis, we can conclude that all the values observed in the present study were included in the normal range of AST activity. In this study, treatments did not display the hepatoprotective activity effect suggested by others authors (Lang et al., 1990 and Erdogan et al., 2005).

\section{CONCLUSION}

From the results of this experiment, it can be concluded that the addition of silymarin to broiler diets significantly improved the body weight gain and feed conversion indices all over the period of raising. L-carnitine improved growth performance of broilers at growing-finishing period (high energy diet). Finally, it is recommended that we can use both silymarin and L-carnitine as feed additives at growing-finishing period.

\section{REFERENCES}

Arenas, J.; Rubio, J.C.; Martin, M.A. and Campos, Y. (1998): Biological roles of L-carnitine in perinatal metabolism. Early Human Development, 53, 43-50.

Bremer, J. (1983): Carnitine: metabolism and functions. Physiol. Rev., 63, 1420-1480.

Chakarverty, A. and Parsad, J. (1991): Study on the effect of Milk Thistle extract on the performance of broiler chicks. Ind. Poult. Advis., 24(9):37-38.

Coles, E.H. (1986): Veterinary Clinical Pathology. 4th Ed. W.B. Saunders Company, Philadelphia, PA, USA. 
Crocenzi, Fa. and Roma, Mg. (2006): Silymarin as a new hepatoprotective agent in experimental cholestasis: New possibilities for an ancient medication. Curr Med Chem.,13: 1055-1074.

Deng, K.; Wong, C.W. and Nolan, J.V. (2006): Longterm effects of early-life dietary Lcarnitine on lymphoid organs and immune responses in leghorn-type chickens. Journal of Animal Physiology and Animal Nutrition, 90: 81-86.

Ding, T.M.; Tian, S.J.; Zhang, Z.X.; Gu, D.Z.; Chen, Y.F.; Shi, Y.H. and Sun, Z.P. (2001): Determination of active component in silymarin by RP-LC and LC/MS. Journal of Pharmaceutical and Biomedical Analysis, 26(1): 155-161.

Erdogan, Z.; Erdogan, S.; Celik, S. and Unlu, A. (2005): Effects of ascorbic acid on cadmiuminduced oxidative stress and performance of broilers. Biological Trace Element Research, 104, 19-32.

Fraschini, F.; Demartini, G. and Esposti, D. (2002): Pharmacology of silymarin. Clin Drug Invest., 22: 51-65.

Golzar Adabi, S.H.; Cooper, R.G.; Ceylan, N. and Corduk, M. (2011): L-carnitine and its functional effectsin poultry nutrition. Worlds Poultry Science Journal, 67: 277-288.

Gowda, S.K. and Sastry, V.R.B. (2000): Neem (Azadirachta-indica) seed cake in animal feeding-scope and limitation Review. AsianAust. J. Anim. Sci., 13(5): 720-728.

Harpaz, S.; Becker, K. and Blum, R. (1999): The Effect of Dietary L-Carnitine Supplementation on Cold Tolerance and Growth of the Ornamental Cichlid Fish Pelvicachromis Pulcher-Preliminary Results. Journal of Thermal Biology, 24: 57-62.

Hossininezhad, M.M.; Irani, M. and Seidavi, A. (2011): Dietary effects of L-carnitine supplement on performance and blood parameters of broiler chickens. J. Food. Agric. Envir., 9(3\&4): 475-481.

Kalaiselvi, C.J. and Panneerselvam, C. (1998): Effect of L-carnitine on the status of lipid peroxidation and antioxidants in aging rats. Journal of Nutritional Biochemistry, 9: 575581.

Lang, I.; Nekam, K. and Gonzales-Cabello, $R$. (1990): Hepatoprotective and immunological effects of antioxidant drugs. Tokai J. Experi. Clin. Medi., Vol. 15: pp. 123-127.

Lien, T.F. and Horng, Y.M. (2001): The effect of supplementary dietary L-carnitine on the growth performance, serum components, carcass traits and enzyme activities in relation to fatty acid beta-oxidation of broiler chickens Br. Poult. Sci., 42, 92-95.

Lumeij, J.T. (1997): Avian clinical biochemistry. In: J.J. Kaneke, J.W. Harvey, and M. L. Bruss (eds) clinical biochemistry, 5th edn. Academic press, San Diego, CA. PP. 857-883.
Magliulo, E.; Carosi, P.; Minoli, L. and Gorini, S. (1973): Studies on the regenerative capacity of the liver in rats subjected to partial hepatectomy and treated with silymarin. Arzneimittel-Forschung.1973; 23:161-7.

Murali, P.; George, S.K.; Ally, K. and Dipu, M.T. (2015): Effect of L-carnitine supplementation on growth performance, nutrient utilization, and nitrogen balance of broilers fed with animal fat. Veterinary World, vol.8: 482: 486.

N.R.C. (1994): Nutrient requirements of poultry. $9^{\text {th }}$ ed National Academy press, Washington, D.C., USA.

Opletal, L. and Skrivanova, V. [ed.] (2010): Natural substances and their biological activity (in Czech). Prague: Karolinum.

Parsaeimehr, K.; Farhoomand, P. and Najafi, $R$. (2012): The effects of L-carnitine with animal fat on performance, car $\neg$ cass characteristics and some blood parameters of broiler chickens. Ann. Biol. Res., 3(7): 3663-3666

Rabie, M.H.; Szilagyi, M.; Gippert, T.; Votisky, E. and Gerendai, D. (1997): Influence of dietary L-carnitine on performance and carcass quality of broiler chickens. Acta Biol. Hung., 48(2): 241-252.

SAS Institute (1998): SAS User's Guide: Statistics. SAS Institute, Inc., Cary, NC.

Skottova, N. and Krecman, V. (1998): Silymarin as a potential hypocholesterolaemic drug. Physiol Res, 47: 1-7

Steel, R.G.D. and Torrie, J.H. (1981): Principles and procedures of statistics: A biometrical approach. 2nd. Ed. McGraw-Hill, Singapore.

Suchy, P.; Strakova, E.; Kummer, V.; Herzig, I.; Pisarikova, V.; Blechova, R. and Maskova, J. (2008): Hepatoprotective effects of milk thistle (Silybum marianum) seed cakes during the chicken broiler fattening. Acta Veterinaria Brno, 77(1): 31-38.

Tabeidian, S.A.; Ghafoori, M.; Bahrami, Y.; Chekani-Azar, S. and Toghyani, M. (2010): Effect of different levaels of dietary fat on broiler performance and production cost with emphasis on calcium and phosphorus absorption. Glob. Vet., 5(1): 54-60.

Tedesco, D. (2001): The potentiality of herbs and plants extracts as feed additives in livestock production. Zootecnia e Nutrizione Animale, 27(3-4): 111-133.

Whitehead, C.C.; McCormack, H.A. and McTeir, L. (1997): Effects of dietary carnitine supplementation on cell integrity in young chicks under acute heat stress. Roslin Institute, Midlothian EH25 9PS, Scotland.

Wojcik, S.; Niedzwiadek, T. and Adamczyk, M. (2002): The effectiveness of silymarin in finishing broilers. Biuletyn Naukowy Przemyslu Paszowego, 41(1): 5-14.

Yousefi, M.; Shivazad, M. and Sohrabi-Haghdoost, M.I. (2005): Effect of dietary factors on 
induction of fatty liver-hemorrhagic syndrome and its diagnosis methods with use of serum and liver parameters in laying hens. International Journal of poultry Science 4, 568572.
Zhou, T.X.; Chen, Y.J. and Yoo, J.S. (2009): Effects of chitooligosaccharide supplementation on performance, blood characteristics, relative organ weight, and meat quality in broiler chickens. Poult. Sci., v.88, p.593-600.

\section{اثر اضافة الكارنيتين والسيليمارين على كفاءة الأداء وبعض قياسات الام في بارىى التسمين \\ محمد عبل الله موسي ، أحمد السبإ عصدان \\ E-mail: dr_m_mousa@yahoo.com Assiut University web-site: www.aun.edu.eg}

تم در اسة كفاءة الاداء وخصائص الذبائح وبعض من قياسات الدم في بدارى التسمين المغذاه على علائق مضافا اليها الـكارنيتين

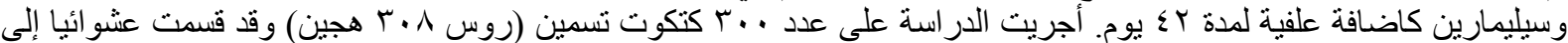

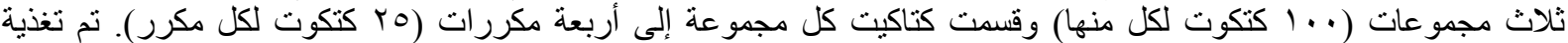

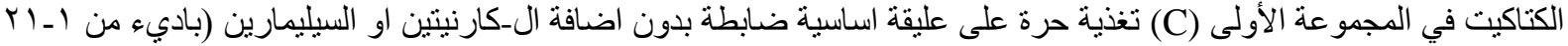

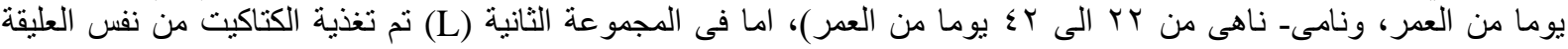

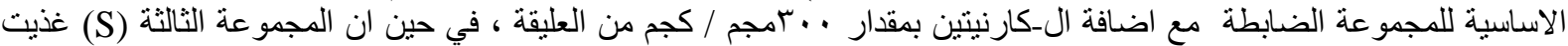

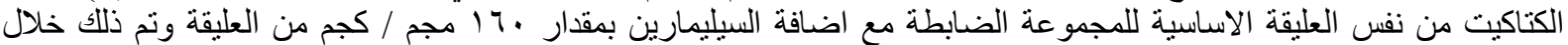

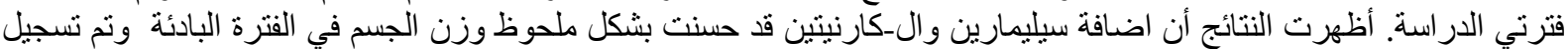

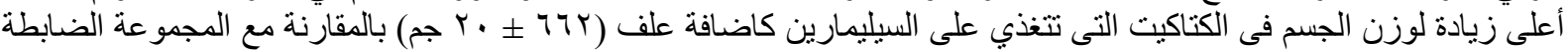

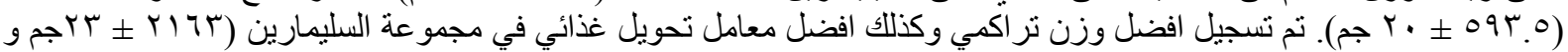

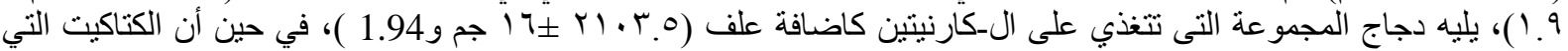

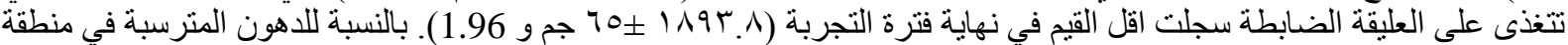

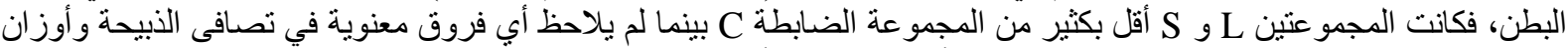

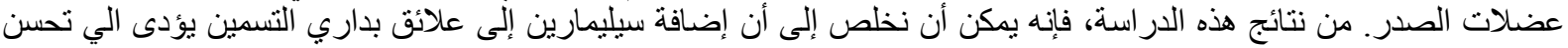

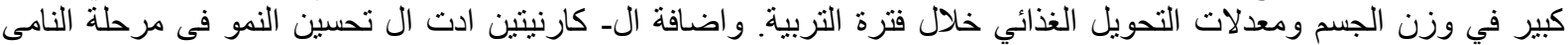

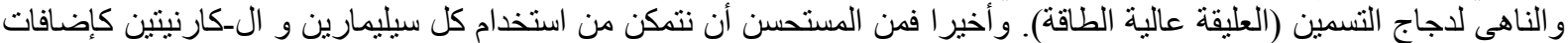
غذائية في فترة النامى و الناهى لاجين الناج التسمين. 